whatever when the animals are already attacked, and any of the viscera involved.

In conclusion, we may note that a steer which was thought to have passed through an attack of Anthrax in June I 886 was again attacked the following May and died. This is the only case noticed of a double attack. In I 887 seven cases occurred in May. Six of them were of the enteric form, and all died. This month was very dry, no rain having fallen for weeks. Would this explain diarrhoea becoming all at once so important a feature, as in the previous years no such condition was noticed? Between 1852 and I882 not more than four or five cases of Anthrax had occurred on this farm. The animals were found dead, and the cause of death was not suspected. About the latter year however some drains had become choked, and redraining had been decided upon, on the very plot where the first death occurred in 1882 . And from the fact that the fatal cases linger longer than formerly, and that the victims are now chiefly among the one year olds, it is hoped that the bacillus is becoming less active, and will again get quiescent, as the greatest care has been exercised in the disposal of the dead.

From a few of the earlier cases the hides were removed, and one carcase was sent to the kennels, but no accidents have been reported. On an adjoining farm a cat died from eating the flesh of a bullock dead of Anthrax, the skin of which had been partly removed.

\title{
COMMINUTED FRACTURE OF THE OS SUFFRAGINIS
}

By ArCH. BAIRD, M.R.C.V.S., Royal Veterinary College, Edinburgh.

THE case derives its interest from the almost innumerable pieces into which the bone was broken, and from the simple manner in which the accident occurred.

The subject was a three-parts-bred grey mare, five years old, in good condition. She was being ridden at a trot over one of the very slippery causewayed streets of Edinburgh, when she suddenly lost her footing and came down. She got up again immediately without assistance, but it was at once perfectly evident that a serious fracture of the near fore pastern had taken place. I saw the mare within half an hour of the occurrence, and had her shot on the street where she stood. I afterwards had the limb cut off at the knee for the purpose of postmortem examination, and the appearances the parts presented were as follows.

The skin was unbroken, but on dissecting down to the bone, I discovered the latter to be simply a shattered mass, the fractures extending into the fetlock joint above and the pastern joint below. The articular cartilages of the os metacarpi and os coronæ at the points of fracture showed slight attrition. The broken pieces of bone (the larger pieces at any rate) were extremely irregular in shape, and varied in size from a piece about twice as large as the navicular bone to small granules no larger than the particles of oatmeal. I was unable accurately to count the number of pieces of bone in the fresh state, and accordingly had the part carefully boiled, so as to separate the soft tissues. With the help of two students I afterwards counted 
out i 80 pieces, and there were still left numerous small particles which could be felt but not separated from the water.

I have been induced to bring this case into notice, as quite recently I observed one of a similar nature reported at a meeting of one of the Veterinary Associations. In the latter instance the bone was broken (if I remember aright) into fifty pieces. At the time I read the report I considered the case a very extraordinary one, and probably unprecedented, but judge of my surprise when in about a week afterwards the case which I have just described took place in my own experience.

One would be inclined to imagine it quite outside the bounds of possibility that a short, strong bone like the os suffraginis should be so utterly destroyed by any force that could be produced by a simple fall.

\section{EQUINE TUBERCULOSIS.}

By BenJamin FreER, M.R.C.V.S., Uppingham.

EARLY in September I886 I was requested to look at a well-bred yearling colt which I had castrated in the previous June, and which, the owner said, had not done well since. I saw him the following day, and careful examination showed nothing resulting from the operation. The colt looked starved, and had lost his muscle, in fact, had evidently been doing badly for some time. I attributed this partly to the poverty of the land, and partly to the fact that for some time we had been having very inclement weather. I ordered him into a roomy and comfortable box, recommended a diet of bran, oats, good hay, plentiful supply of rock salt, and good water, and sent him a dozen powders containing ferri sulph., gentian, etc., fully expecting to find an improvement the next time I called. I was not disappointed, and for some time the improvement continued, but, passing one day, I was asked to call as the colt was in pain. I found him rolling about, sweating profusely, and tympanitic. Having nothing better with me, I gave him an 8-oz. bottle of wound liniment-ol. tereb. and ol. olivæ, and this gave almost instant relief. However, he now had occasional attacks of this sort, which soon became more frequent, although they were invariably relieved by a draught containing ather sulph. and tinct. opii. Every time I saw him it became more and more apparent that he was doomed. I gave him sodæ hyposulph. and nux vomica, potas. chlor,, cinchona, liq. arsenicalis, ol. morrhux, etc., but nothing seemed to do him any permanent good. As I had sometime previously given it as my opinion that it was a case of consumption of the bowels, the owner at last determined to destroy him, but was saved the trouble as the animal went off suddenly during one of his periodic attacks.

I made a post-mortem examination the same day, and found the mesentery studded with apparently tuberculous deposits. One mass in the lumbar region, consisting of a number of tumours of various sizes, was undergoing the softening process. The bowels were very pale and full of wind. Kidneys and liver pale, the latter having several small deposits in its substance. 